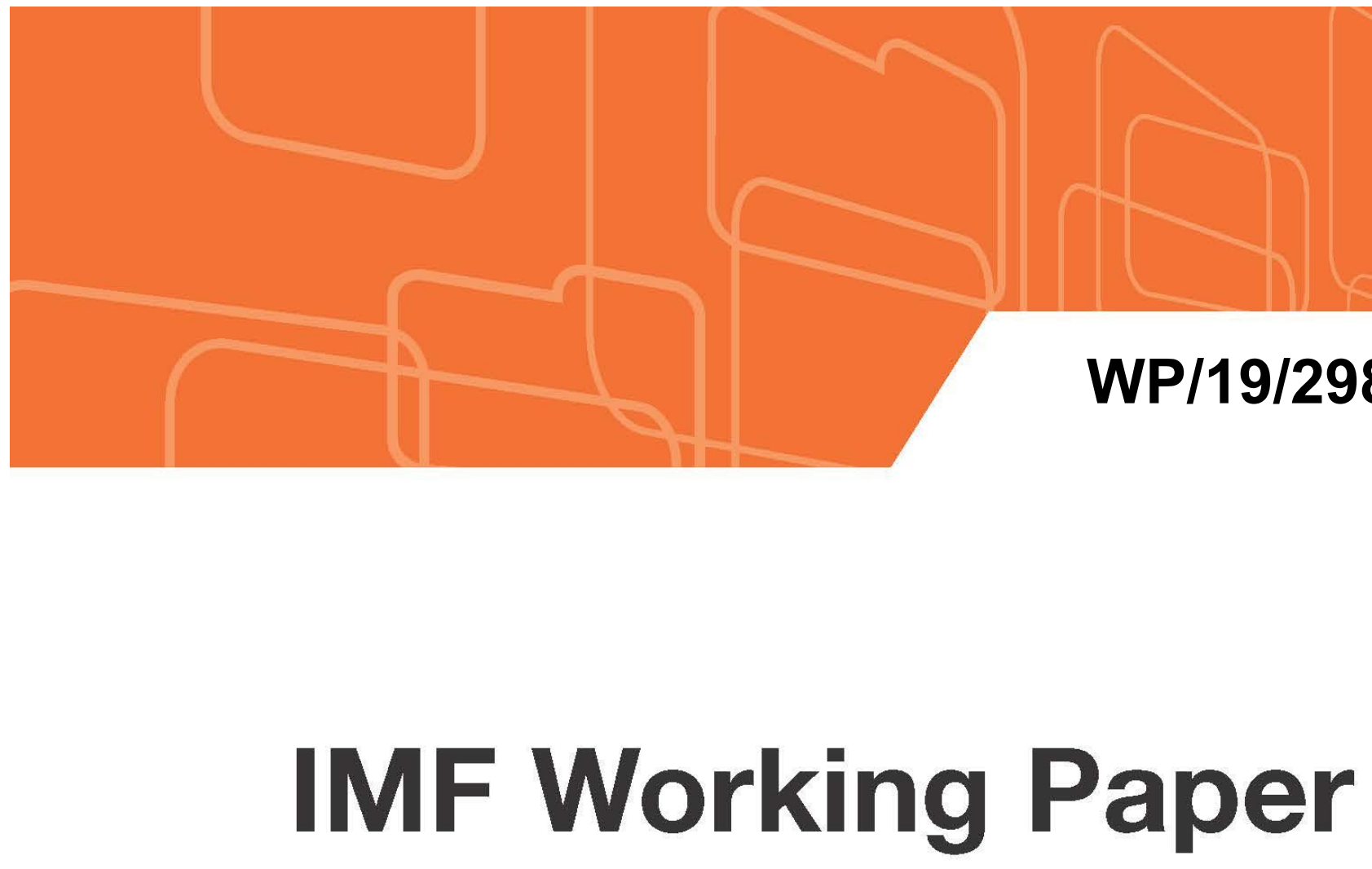

\title{
Political Costs of Tax-Based Consolidations
}

\author{
by Chuling Chen, Era Dabla-Norris, Jay Rappaport \\ and Aleksandra Zdzienicka
}




\title{
IMF Working Paper
}

Asia and Pacific and Fiscal Affairs Department

Political Costs of Tax-based Consolidations

\section{Prepared by Chuling Chen, Era Dabla-Norris, Jay Rappaport,} and Aleksandra Zdzienicka*

Authorized for distribution by Era Dabla-Norris

December 2019

IMF Working Papers describe research in progress by the author(s) and are published to elicit comments and to encourage debate. The views expressed in IMF Working Papers are those of the author(s) and do not necessarily represent the views of the IMF, its Executive Board, or IMF management.

\begin{abstract}
This paper studies the impact of tax-based consolidations on reelection outcomes. Using a granular database of tax-based consolidations for a panel of 10 OECD countries over the last 40 years, we find that tax reforms are politically costly but some reforms are costlier than others. Measures aimed primarily at reducing existing deficits and debt are costlier than tax consolidation policies for improving long-term growth prospects. Electoral costs are particularly high for broad-based indirect tax and corporate tax reforms. Voters tend to penalize governments less if tax consolidations are announced early in the government's term or if the government has a strong political mandate. Favorable economic conditions increase public support for tax-based consolidations. Personal income tax reforms are electorally salient if the reforms are frontloaded, announced during recessions, and in less progressive tax systems.
\end{abstract}

JEL Classification Numbers: H2, H3, P16

Keywords: Fiscal Consolidation, Tax Reforms, Political Economy

Author's E-Mail Address: cchen@imf.org, edablanorris@imf.org, jrappport@imf.org, azdzienicka@imf.org

\footnotetext{
* We are grateful to A. Alesina, B. Bakker, S. Cerovic, V. Crispolti, P. Dempsey, D. Furceri, V. Gaspar, F. Lima, G. Medina, A. Mineshima, D. Prihardini, and A. Schaechter, as well as participants of various IMF FAD seminars for comments and suggestions. We also thank F. Lima for sharing the data on tax and fiscal variables. Patricia Quiros and Von Allena provided valuable editorial assistance.
} 
ABSTRACT

II. EMPIRICAL APPROACH

A. Data

B. Empirical Framework 10

III. HOW DO TAX REFORMS AFFECT REELECTIONS OUTCOMES? 11

A. Baseline 11

B. Robustness Checks 13

IV. WHICH TAX REFORMS ARE COSTLIER? 15

A. Reform Types: PIT, CIT, and Indirect Tax Reforms ___________________________

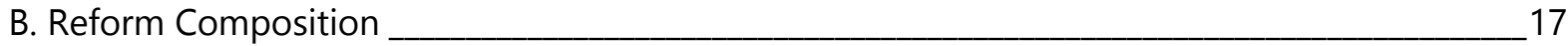

C. Motivation Behind Reforms ____________________________________

V. WHEN ARE TAX REFOMS MOST COSTLY? _______________________________

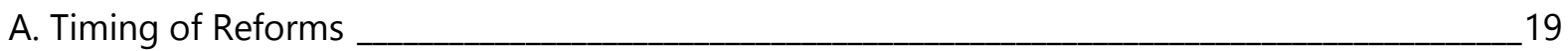

B. Role of Political Conditions_____________________________________________________

C. Role of Economic Factors _________________________________

VI. CONCLUSIONS

FIGURE

1. Distribution of Tax Reforms 9

\section{TABLES}

1. Effects of Tax Reforms on the Probability of Reelection in OECD Countries (marginal effects)

2. Frequency of Tax Reforms depending on the Popularity of the Government (in percent) 13

3. Robustness Tests: Effects of Tax Reforms on the Probability of Reelection of the Government Party (marginal effects)

4. Effects of Different Taxes on the Probability of Reelection of the Government (marginal effects)

5. Effects of Tax Reforms on the Probability of Reelection of the Government depending on the Composition of Reform (marginal effects)

6. Effects of Consolidation Tax Reforms on the Probability of Reelection of the Government depending on the Motivation of the Reform (marginal effects)

7. Effects of Tax Reforms on the Probability of Reelection of the Government dpending on Timing of Reforms (marginal effects)

8. Effects of Tax Reforms on the Probability of Reelection of the Government depending on the Political Support for the Government (marginal effects)

9. Effects of Tax Reforms on the Probability of Reelection of the Government depending on Political Orientation (marginal effects) 
10. Effects of Tax Reforms on the Probability of Reelection of the Government depending on Growth Regimes (marginal effects)

11. Effects of Tax Reforms on the Probability of Reelection of the Government depending on PIT Progressivity (marginal effects)

REFERENCES 25

ANNEXES

A1. Data Sources 27

A2. Selected Summary Statistics 28

A3. Effects of Tax Reforms on the Probability of Reelection of the Government: Alternative Database 29

A4. Differential Impact of Positive versus Negative Tax Reforms 29

A5. Effects of Tax Reforms on the Probability of Reelection of the Government: Alternative Measures of Economic Perfromance 30

A6. Effects of Tax Reforms on the Probability of Reelection of the Government: Alternative Standard Errors Clustering 31 
"We all know what to do, we just don't know how to get reelected after we've done it."

(J.C. Juncker 2007) ${ }^{1}$

\section{INTRODUCTION}

Large fiscal deficits and concerns about debt sustainability in many advanced economies in the wake of the Global Financial Crisis increased pressure to adopt fiscal consolidation measures. The composition of these measures and their impact on the macroeconomy, particularly in times of severe economic crisis, has been the subject of considerable debate in academic and policy circles. Limited progress with consolidation efforts in some cases has also raised concerns about the political fallout from such policies. Conventional wisdom suggests that fiscal adjustment is costly for elected leaders and governments responsible for their implementation: voters penalize them at the polls.

Fiscal consolidation measures improve stabilization and growth in the long-term but can entail short-term economic costs. Evidence also suggests that tax-based consolidations are associated with larger output declines than spending-based measures. ${ }^{2}$ Importantly, the benefits and costs of spending cuts and tax increases are rarely evenly distributed across the electorate. This heterogeneous impact renders consolidation efforts politically costly to implement and may also explain why fiscal adjustments are delayed. ${ }^{3}$ Studies also find that corporate and personal income taxes have differential macroeconomic impacts (Mertens and Ravn 2013; Dabla-Norris and Lima 2018). These considerations point to the importance of investigating the political consequences of tax-based fiscal consolidations and examining how electoral costs depend on which taxes are raised (and, consequently, the different interest groups affected). ${ }^{4}$

The link between economic policy and economic performance before elections and the votes that an incumbent leader or government receives, however, is not clear cut. Electoral incentives may induce incumbent governments to reduce taxes (or increase spending) to improve their chances of being reelected. ${ }^{5}$ This could be because rational voters are imperfectly informed and believe that more competent policymakers can provide expansionary fiscal policies without necessarily incurring higher deficits (Rogoff 1990). This line of argument suggests that budget deficits are popular and fiscal consolidation is not (i.e., it increases the likelihood of electoral defeat for incumbent governments). On the other hand, fiscal consolidation may not be an electoral "deal

\footnotetext{
${ }^{1}$ The Economist (2007), "The Quest for Prosperity", March 15th.

2 Studies typically find a larger negative output impact of tax-consolidation policies (Guajardo et al., 2014; Alesina, Favero, and Giavazzi 2015).

3 Theory suggests that the median voter may resist fiscal policies that decrease redistribution (Meltzer and Richards 1981). Alesina and Drazen (1991) model a "war of attrition" in which organized groups with a strong influence on the polity manage to postpone reforms, even when the latter are necessary and unavoidable.

${ }^{4}$ Citizens can have different views about taxation based on their position in the income distribution, and political systems affect whose interest are represented and how. Similarly, organized interests may have advantages in securing favorable policy outcomes in return for electoral contributions that can be used to persuade other voters (see Alt, Preston, and Sibieta, 2010, for a comprehensive discussion of the politics of tax reform).

${ }^{5}$ Further, if a "strong economy" gains votes, incumbents may use expansionary fiscal policy to stimulate the economy. See Drazen (2001) and Brender and Drazen (2008) for a discussion on political budget cycles.
} 
breaker" if voters are fiscally prudent themselves and if they approve of tight fiscal policies (Alesina, Perotti, and Tavares 1998; Brender and Drazen 2008). Similarly, the electorate may place less weight on fiscal adjustments-even when unpopular-if undertaken alongside other beneficial reforms or if other political attributes matter to voters (e.g., ideology of party). ${ }^{6}$

Empirical evidence that fiscal consolidations are electorally costly is inconclusive. Some studies find that voters do not systematically punish governments for implementing such policies (Alesina, Carloni, and Lecce 2013), while others find that tax-based consolidations have a larger electoral impact than spending-based consolidations (Alesina et al., forthcoming). ${ }^{7}$ Political consequences of tax consolidations also likely depend on the composition of tax reforms and on prevailing political and economic conditions (Ilzetzki 2018). ${ }^{8}$ For instance, some studies find that lowering indirect taxes by the incumbent government prior to elections increased the likelihood of reelection, but the impact of direct taxes is not statistically significant (Ehrhart 2013).

This paper examines the political consequences of tax-based consolidation measures in a systematic manner. Specifically, we address three questions. First, how do tax reforms affect the probability of reelection of the incumbent government party or its leader? Second, how do electoral costs vary depending on the type and design of tax policy measures? Third, how do initial political and economic conditions underpinning tax consolidations impact reelection outcomes?

We examine these questions by drawing upon a narrative dataset of tax-based fiscal consolidations compiled by Dabla-Norris and Lima (2018) at a quarterly frequency for 10 advanced economies over the last forty years. ${ }^{9}$ This unique database provides comprehensive information on the precise announcement and implementation dates of various implemented direct and indirect tax changes. It also includes the magnitudes of announced and implemented reforms and the motivation behind each individual tax policy action, as opposed to broad tax- or spending-based consolidation plans. To exploit the granularity of tax policy reforms, avoid further aggregation of tax reform indicators, and analyze the role of economic and political conditions within a limited size of our country sample, our estimation includes all quarters, not only the quarters with the elections. ${ }^{10}$ The granularity of this dataset and its mapping with electoral outcomes distinguishes our paper from previous studies.

\footnotetext{
${ }^{6}$ Lindbeck and Weibull (1987) and Dixit and Londregan (1988) develop probabilistic voting models which assume that voters choose between parties on the basis of policies proposed as well as a random component. The implication is that a small change in a policy platform will not lead to a total change of the support from the incumbent to the opposition, but only leads to a change in the probability of support.

${ }^{7}$ Alesina, Favaro, and Giavazzi (2019) show that this effect is not robust, but Alesina and others (forthcoming) provide evidence that tax-based austerity reduces reelection probabilities.

8 Ilzetzki (2018) develops a model of lobbying between special- and general-interests in which large changes in the tax code may be easier to enact than marginal reforms. He shows that politically feasible tax reforms occur when fiscal needs are large. See also Persson and Tabellini (2002).

${ }^{9}$ The country sample includes Australia, Austria, Canada, Germany, France, Italy, Portugal, Spain, the United Kingdom, and the United States.

${ }^{10}$ We also test whether the constriction of our panel affects the results in an alternative specification with dependent variables including only the election outcomes in the election quarters (Table 2.)
} 
Our main findings can be summarized as follows:

- Tax reforms are politically costly, but some measures are costlier than others. Tax-based consolidations significantly lower the probability of reelection of the incumbent government party and its leader. Electoral costs are higher following broad-based indirect tax reforms and reforms affecting specific interest groups (e.g., corporate income tax reforms). Consolidation tax measures primarily aimed at reducing existing fiscal deficits and debt are costlier than other tax increases motivated by long-term growth or administration efficiency considerations.

- Timing and design of reforms matter, particularly for indirect tax and PIT reforms. Political costs are lower for reforms implemented earlier in the government's mandate when the incumbent government has higher political capital. Electoral outcomes are materially impacted by frontloaded consolidations, particularly in the case of personal income taxes.

- Political support and initial economic conditions determine reelection prospects. Electoral costs of tax-based consolidations are higher if the country's ruling coalition is right-wing, if the government has weak public support, and when tax reforms are implemented during recessions. Personal income tax changes are electorally salient if reforms are announced during recessions, and if the tax system is less progressive.

Our results are robust to a battery of robustness tests and alternative specifications.

The rest of the paper is organized as follows. Section II discusses the empirical approach and data. Section III presents the baseline results and a battery of robustness checks. Section IV examines the design of tax reforms' impact, while Sections $V$ analyzes the political costs of tax policy measures depending on initial political and economic conditions. Section VI concludes.

\section{EMPIRICAL APPROACH}

\section{A. Data}

\section{Tax Reforms}

To analyze the political costs of tax-based consolidation measures, we use the narrative database of tax reforms identified by Dabla-Norris and Lima (2018) for 10 OECD countries over the period 1980Q1 to 2016Q4. Building on the narrative datasets constructed by Devries et al. (2011), and later extended by Alesina et al. (2015), who distinguish between fiscal consolidations that are largely tax-based and those that are largely spending-based, this database creates a comprehensive list of all announced tax policy consolidations and codes each of the individual tax policy measures involved. Specifically, the dataset contains information on announcement and implementation dates of individual direct and indirect tax reforms with the exact dates of their announcement and implementation, even if these reforms are announced simultaneously or as a part of the reform package. It also contains information regarding the expected annual revenue yields using forecasts produced by country authorities when the tax measures were announced and specific motivation (e.g., long-term growth or administrative considerations and 
consolidation) underlying each policy change. ${ }^{11}$ Announcement dates are the first time the measure was formally proposed by the government, for example through a formal communication by a senior official (such as the President, Prime Minister or the Minister of Finance), or by the introduction of draft legislation to Parliament, such as a draft Budget law. The implementation date is the first moment when revenue impacts are non-zero.

Using this information, we group tax reforms into personal (PIT) and corporate (CIT) income and indirect tax reforms (mainly value added, sales, and excises tax measures). We also examine the magnitude, composition (frontloaded versus backloaded), and timing associated with each tax reform.

To minimizes endogeneity concerns we adopt two approaches. First, as reforms could be implemented to smooth contemporaneous economic fluctuations, which could, thus, affect reelection outcomes, we focus on consolidation reforms that are introduced for reasons other than current stabilization purposes. Second, as the endogeneity issue might arise if governments implement or not tax consolidation reforms depending on their initial public support, which in turn can affect the reelection outcomes we assess the direction of the bias and how it affects our results (Section III.B). We also include a battery of controls and robustness tests and distinguish between reforms undertaken for consolidation and long-term growth considerations. As an additional robustness check, we use annual fiscal consolidation measures (Table A3) constructed by Alesina, Favero, and Giavazzi (2015).

\section{Reform Episodes}

We construct a reform indicator $(\mathrm{R})$ for direct taxes and indirect taxes. The reform indicator takes the value of the total expected revenue yield (in percent of GDP) at the time of reform announcement, and zero otherwise. Focusing on expected revenue yields at the announcement date mitigates the issue of "fiscal foresight." This is because taxpayers are likely to adjust their behavior before tax measures are implemented if they are known in advance. Ignoring these anticipation effects can lead to biased estimates of the impact of tax policy changes (see, for example, Mertens and Ravn, 2012). For the same reason, we consider the cumulative expected revenue yields associated with the consolidation, rather than expected yields over time (in the case of multiyear reforms). Further, in the case of the tax reform taking place in the same quarter as part of a package, the announcement date corresponds to the announcement date of the first reform announced in the package. We also directly account for the magnitude of reforms. This allows for more precise estimates of the reform impact and minimizes the drawback of classifying tax reforms as a dummy based on arbitrary thresholds.

Among tax consolidation measures, 33 percent are PIT reforms, 30 percent CIT reforms and 30 percent are indirect tax consolidations (Figure 1A). Fiscal consolidations often include both tax increases and decreases. The average expected revenue yield is about 0.7 percent of GDP, and

\footnotetext{
11 The first category includes tax changes that were primarily aimed at increasing long-run growth. This category also includes tax reforms motivated by a desire to promote competitiveness, protect tax revenue or generally increase the efficiency of the tax system. Consolidation measures are those exogenous measures taken primarily to reduce an existing fiscal deficit or, more broadly, to ensure that public debt remains sustainable. See Dabla-Norris and Lima (2018) for details.
} 
around 1.3 percent of GDP for tax increases (Annex A2). Expected revenue yields of indirect tax consolidations are slightly higher than for direct tax reforms (Figure 1B). Almost half of the consolidation reforms aimed to address long term structural challenges; reforms triggered by high deficit and debt concerns accounted for 38 percent of consolidation episodes (Figure 1C). A majority of tax reforms in our sample are announced shortly after the previous elections and the frequency of reforms decreases closer to the date of reelection (Figure 1D).

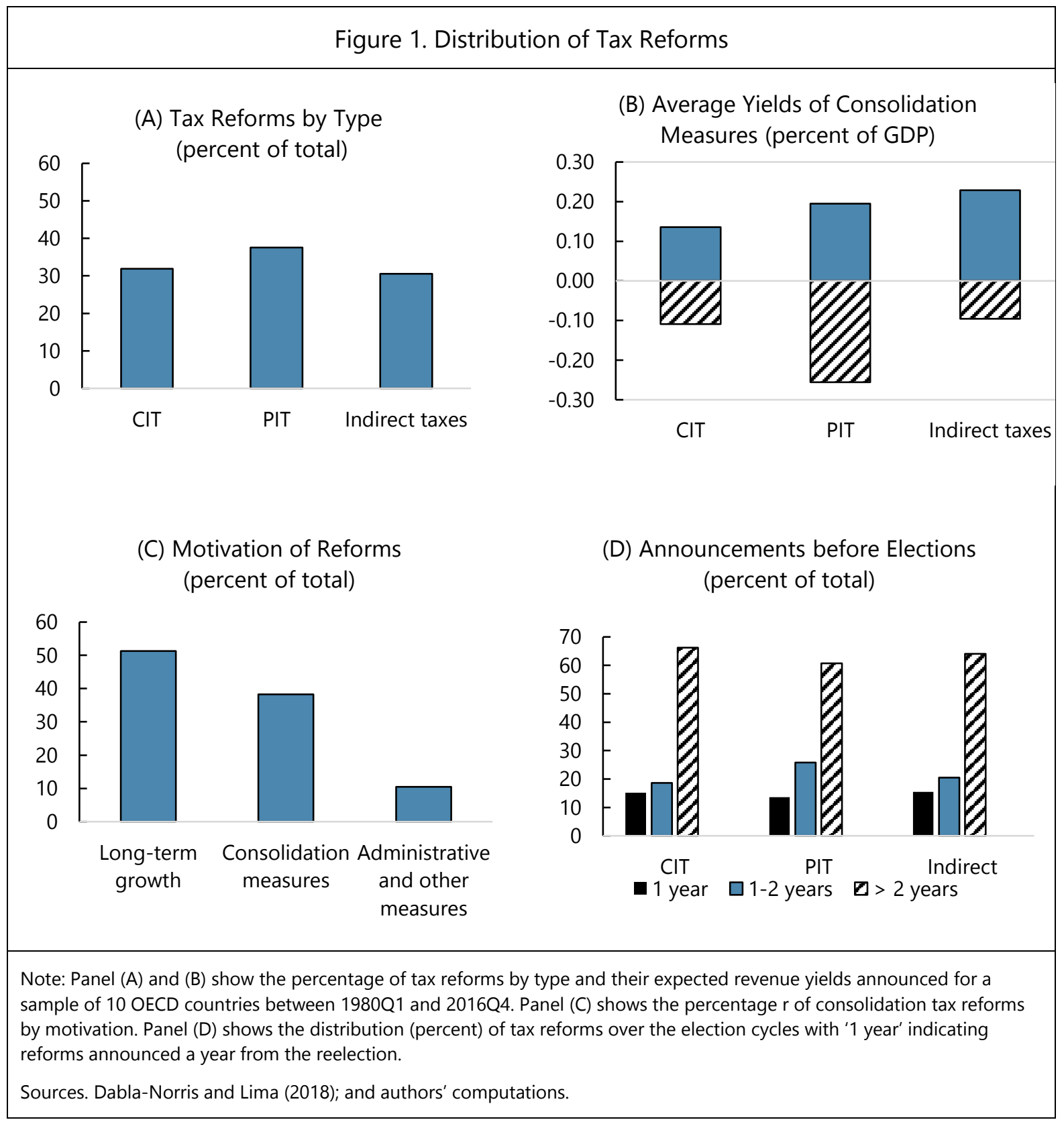

\section{Reelection Outcomes}

We determine political costs based on three different reelection outcomes. First, we use a binary indicator that takes the value of 1 if the incumbent ruling (majority) government party is reelected 
and, zero otherwise. Specifically, the dummy variables take value of $1(0)$ in all quarters between the "first election" and the reelection if the incumbent government is (not) reelected. Second, we apply a similar approach for the reelection of the leader of the ruling government party and include only observations where the leader is running for reelection himself (either as the leader of his party in a parliamentary election or personally in a presidential one). Third, we distinguish between cases where the government party is reelected with the same or larger number of votes (the dummy variable takes the value 1) and when the government is reelected but with a lower number of votes (the dummy variable takes the value 0 ).

We include all quarters in the sample to explore granular information about the type and timing of tax reforms, and the role of political and economic factors underpinning reform implementation. To test whether the structure of our panel affects the results, we consider an alternative specification with only elections quarters (see subsection on Robustness Checks). The results are broadly similar but significantly lower number of observations and require additional aggregation of tax reform measures and related information on each reform.

All election outcome data are taken from taken from Global Elections Database, Database of Political Institutions, and National Election Database (see Annex A1 for details). In total, our sample consists of 89 election episodes in which the government ruling party was reelected about 55 percent of the time and its leader about 44 percent of the time.

\section{B. Empirical Framework}

We estimate the political costs of tax-based consolidation measures using the following panel probit regression:

$$
y_{i t}=e_{t}+\beta T_{i t-k}+\theta Z_{i t}+\varepsilon_{i t}
$$

Where $i$ denotes country and $k$ denotes quarters between the first election and the reelection date. The dependent variable $y_{i t}$ is a political dummy variable that takes the value of 1 if the incumbent party or leader is reelected, and 0 otherwise (see above). The coefficient $\beta$ captures the effects of direct and indirect tax reforms $T$ announced during the current term of the incumbent government (that is, before the reelection date).

$Z_{i t}$ is a vector of controls that could affect reelection outcomes which are potentially correlated with the introduction of tax consolidation reforms (see Annex A1 for details on data sources). These include contemporaneous and lagged changes in the structural fiscal balance to account for the behavior of fiscal aggregates (revenue and spending). We use changes rather than the levels of these variables, as we believe that changes better reflect the impact on policy outcomes. Our indicator of macroeconomic performance is the real GDP growth per capita growth during the term in office, specifically two years before election, and the initial level of public debt. ${ }^{12}$ Including measures of macroeconomic and fiscal performance over the term also allows us to capture a possible impact of other shocks (e.g., migration). We include a dummy for financial and debt crises, as crises can act as turning points for popular support for the incumbent government.

\footnotetext{
${ }^{12}$ As robustness, we also separately include the real growth rate of GDP in the election year (Table A5).
} 
In line with the literature, we also control for the political orientation of government party or its leader (left, right, or center based on the National Elections database). ${ }^{13}$

As our objective is to exploit the granularity of tax policy reforms, our sample consists of a balanced panel of 10 countries over the period 1988Q1 and 2016Q4. We cluster the standard errors at the time level to account for repeated panels within a given election term. Finally, we also include election-fixed effects $\left(e_{t}\right)$ to control for election-specific developments. ${ }^{14}$

We expand Equation (1) by separating tax reforms into different types of tax reforms as follows:

$$
y_{i t}=e_{t}+\beta_{1} T 1_{i t-k}+\beta_{2} T 2_{i t-k}+\cdots+\beta_{N} T N_{i t-k}+\theta Z_{i t}+\varepsilon_{i t}
$$

where the coefficients $\beta_{1}, \beta_{2, \ldots,}, \beta_{N}$ capture the impact of different types of tax consolidations on the probability of reelection, controlling for the other. We examine the differential impact of direct and indirect tax reforms and distinguish between CIT, PIT, and indirect tax reforms.

To examine whether the design of tax reforms and different political and economic conditions during reform implementation affect the probability of reelection, we extend the baseline as follows:

$$
y_{i t}=e_{t}+D_{i t}^{l}\left[\beta_{l} T_{i t-k}+\theta_{l} Z_{i t}\right]+D_{i t}^{h}\left[\beta_{h} T_{i t-k}+\theta_{h} Z_{i t}\right]+\varepsilon_{i t}
$$

where $D_{i t}^{l}\left(D_{i t}^{h}\right)$ takes the value of 1 when a political or economic variable is below (above) the average of the indicator prevailing at the time of the reform. Following previous theoretical and empirical papers, we focus on political conditions such as the political orientation of the incumbent government and how much political capital it has (as measured by vote share). ${ }^{15} \mathrm{We}$ also analyze the role of economic conditions, including the business cycle.

\section{How Do Tax Reforms Affect Reelections Outcomes?}

This section presents the baseline results and provides a battery of robustness checks.

\section{A. Baseline}

\section{Tax Reforms are Politically Costly}

The baseline results based on Equation (1) suggest that tax reforms entail significant political costs. Table 1 shows that a one percentage point of GDP tax consolidation significantly lowers the probability of the reelection of the incumbent government by about 8 percentage points. The electoral penalty is equally large for the leader of the ruling party, whose likelihood of reelection

\footnotetext{
13 The partisan theory of reforms suggests that different political parties may have different distributional and policy preferences (Alesina and Roubini, 1992).

${ }^{14}$ As a robustness check, we test the impact of tax reforms on the probability of reelections on a country-election year panel (Table 2). To account for a possibility of specific time-election or country-time shocks, we alternatively cluster the standards errors at these levels (Table A6).

15 The partisan theory of reforms suggests that different parties have different distributional and policy preferences (Alesina and Roubini, 1992). According to these models, right-wing governments are more likely to implement market-oriented reforms.
} 
declines by about 7 percentage points following a tax reform of a similar magnitude. Even if the incumbent government party is reelected after announcing the tax reforms, its popularity is significantly lower: a 1-percentage point tax consolidation reform lowers the likelihood of maintaining similar popular support in the next elections, a finding that is statistically significant.

Table 1. Effects of Tax Reforms on the Probability of Reelection in OECD Countries (marginal effects)

\begin{tabular}{|c|c|c|c|}
\hline & $\begin{array}{l}\text { Ruling Party } \\
\text { (I) }\end{array}$ & $\begin{array}{l}\text { Party Leader (PM) } \\
\text { (II) }\end{array}$ & $\begin{array}{c}\text { Number of Votes } \\
\text { (III) }\end{array}$ \\
\hline Tax Reforms & $\begin{array}{c}-\mathbf{0 . 0 8 4} 4^{* * *} \\
(0.029)\end{array}$ & $\begin{array}{c}-\mathbf{0 . 0 7 4} 4^{* * *} \\
(0.025)\end{array}$ & $\begin{array}{c}-\mathbf{0 . 0 2 1 * * *} \\
(0.001)\end{array}$ \\
\hline Structural fiscal balance (change 2 years) & $\begin{array}{c}-0.041^{* * *} \\
(0.006)\end{array}$ & $\begin{array}{c}-0.214^{* * *} \\
(0.005)\end{array}$ & $\begin{array}{c}-0.009 * * * \\
(0.001)\end{array}$ \\
\hline Initial public debt level (percent of GDP) & $\begin{array}{l}-0.141^{* *} \\
(0.062)\end{array}$ & $\begin{array}{l}-0.047 \\
(0.054)\end{array}$ & $\begin{array}{c}0.065^{* * *} \\
(0.002)\end{array}$ \\
\hline Financial crises & $\begin{array}{l}-0.079 * \\
(0.492)\end{array}$ & $\begin{array}{c}0.049 \\
(0.041)\end{array}$ & $\begin{array}{l}0.051^{* * *} \\
(0.011)\end{array}$ \\
\hline Real GDP per capita (log, change over 2 year) & $\begin{array}{c}0.059 * * * \\
(0.012)\end{array}$ & $\begin{array}{c}0.085^{\star * *} \\
(0.111)\end{array}$ & $\begin{array}{c}-0.011^{\star * *} \\
(0.019)\end{array}$ \\
\hline $\begin{array}{l}\text { Political Orientation of the Government (1-right; 0- } \\
\text { left) }\end{array}$ & $\begin{array}{c}0.041 \\
(0.284)\end{array}$ & $\begin{array}{c}0.011 \\
(0.042)\end{array}$ & $\begin{array}{c}-0.052^{* * *} \\
(0.005)\end{array}$ \\
\hline Observations & 860 & 860 & 480 \\
\hline Time FE & Yes & Yes & Yes \\
\hline Clustering & Yes & Yes & Yes \\
\hline (Pseudo) R-squared & 0.074 & 0.050 & 0.030 \\
\hline
\end{tabular}

The impact of other control variables is broadly in line with previous findings in the literature. For instance, an improvement in the fiscal structural balance (a fiscal contraction) during the incumbent's term lowers the probability of reelection. By contrast, the likelihood that the ruling party is reelected increases by about 5 percentage points if economic conditions improve (i.e., if there is a 1 percentage point increase in real GDP per capita in the two years before the reelection). ${ }^{16}$ We also find that voters penalize the ruling party if there is a financial crisis during the incumbent's terms.

\footnotetext{
16 This result is robust to examining real GDP per capita growth rates one year or 6 months before the election (Table A5).
} 


\section{B. Robustness Checks}

We include a battery of tests to check the robustness of our results. We used the likelihood that the government party is reelected as the relevant dependent variable in the rest of the analysis.

\section{Endogeneity Bias}

Our reform episodes are exogenous to the business cycle but can be endogenous to electoral outcomes. Most likely, only a government with strong public support for other dimensions will engage in fiscal consolidation that raises tax liabilities, while weaker governments with lower public support will be less likely to undertake fiscal consolidation plans. This endogeneity will most likely bias the results towards zero, i.e., the negative electoral effects would be lower in the absolute terms ${ }^{17}$ To test this assumption, we define the strength of the government based on the percent of votes in total that the government party received when it was first elected ("first election", hereafter). Strong governments are those that received at least 35 percent of total votes, which broadly corresponds to the cross-country median over the estimation period. Table 2 shows that indeed governments with a stronger public support engage in more tax-based consolidation than weak governments, which implies that the impact of tax-consolidation reforms can have even more adverse effects on the probability of reelections than shown in our results.

\begin{tabular}{|c|c|c|}
\hline \multirow[b]{3}{*}{ Number of tax reforms } & \multirow{3}{*}{$\begin{array}{c}\text { Strong } \\
0.81\end{array}$} & \multirow{3}{*}{$\begin{array}{c}\text { Weak } \\
0.19\end{array}$} \\
\hline & & \\
\hline & & \\
\hline Number of only consolidation reforms & 0.79 & 0.21 \\
\hline
\end{tabular}

\section{Spending-based Consolidations}

Our focus is on tax-based consolidations. However, fiscal consolidations typically depend on both revenue and spending decisions, which are likely interrelated. To ensure that our results are not confounded by changes in government spending, we control for the change in fiscal balance. In addition, we also include all announced spending-based consolidations during the incumbent's term as a robustness check and find that our baseline results remain broadly unchanged (Table 3 , column II).

\footnotetext{
${ }^{17}$ Another endogeneity regarding the timing of election is that in some countries the government has some discretion on when to call elections. To deal with this issue, we could examine if the electoral effects of consolation hold for "exogenous" elections. It would, however, significantly reduce our sample.
} 


\section{Measurement Error}

One concern about including the narrative tax shock directly as a regressor in our estimate is that revenue forecasts produced by country authorities may have significant measurement error, or could even be biased (e.g., if there are political pressures to publish "optimistic" or "pessimistic" forecasts). This measurement error would in turn bias the estimated responses to announced tax reforms. Following Mertens and Ravn (2012) and Dabla-Norris and Lima (2018), we address this issue using an Instrumental Variable (IV) approach in which tax policy reforms are used as an instrument for the tax-to-GDP ratio. The results of this approach reported in Table 3 (column III) are broadly in line with the baseline findings.

\section{Sample Structure}

Our estimation sample includes all quarters and not only election quarters. Although we cluster the standard errors at the time level, this structure of the panel dataset could artificially increase the statistical significance of our estimates. To test whether including all quarters affects our findings we re-estimate Equation (1) dropping all quarters when no elections take place. The results are broadly in line with the baseline (Table 3, column IV). However, it significantly reduces our sample and, most importantly, we lose the granular information about the exact timing of announced tax reforms.

\section{Focus on Tax Increases}

Our focus is on the political cost of tax-based consolidations. In practice, however, the overall consolidation packages (i.e., generating an overall increase in tax revenue) announced at time $t$ could include tax measures aimed at increasing or decreasing tax liabilities. To further explore the different dimensions of tax reforms, we examine separately the political impact of measures aimed at increasing tax revenues (contractionary fiscal measures) controlling for other tax consolidation measures. The results (Table 3, column V) show that a one percentage point of GDP tax-based consolidation lowers the probability of reelection of the government party by 24 percentage points. We also find evidence that large announced tax increases (corresponding to the top fifty percent of tax-based consolidations in the sample) have more detrimental electoral effects (column VI).

\section{Additional Controls}

In our regressions, we focus on tax reforms that are exogenous to contemporaneous macroeconomic fluctuations. However, a consolidation package may be framed as a response to inherited budget deficits if the government has recently changed, or as a forced response to current economic shocks if the government is still the same. As a result, it may be difficult to distinguish between exogenous "deficit consolidation" measures that are motivated by existing budget deficits, which reflect past economic shocks, and endogenous "deficit reduction" measures that target deficits created by current economic conditions, such as a severe recession. To test this, we included a battery of additional controls (e.g., the political support for the ruling party, cumulative GDP growth per capita over the entire election term, GDP growth in the election year, initial characteristics of the tax system, different tax reform lags-which is the time between the announcement of reforms and their implementation-, and changes in government spending). The results are broadly in line with the baseline. We repeat the analysis using tax reforms 
identified by Alesina, Favero, and Giavazzi (2015) for a panel of 16 countries over the period 19802014 and for a similar sample to our baseline including measures of spending-based consolidations (Annex, Table A4).

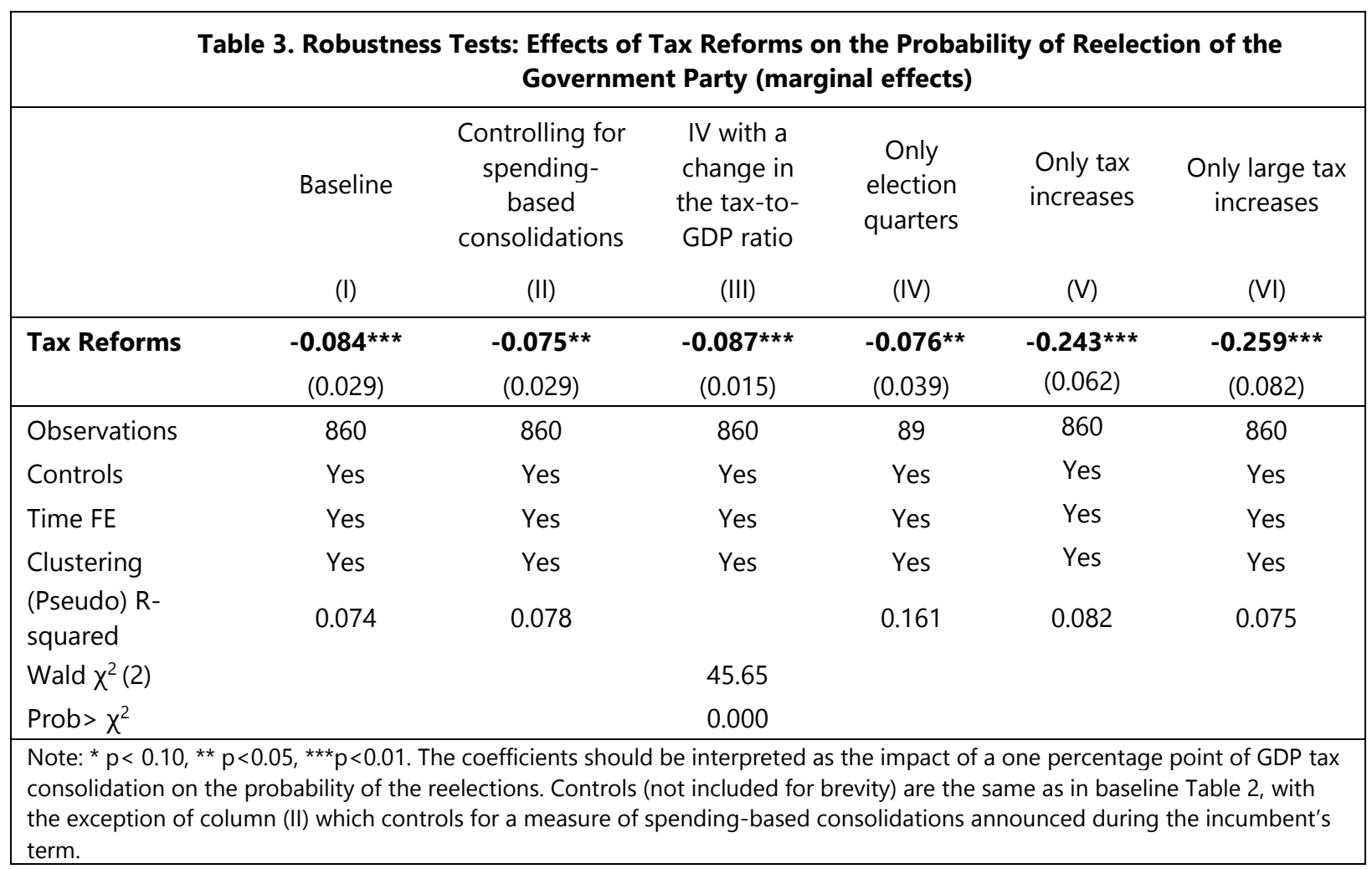

\section{Which Tax Reforms are Costlier?}

This section examines how different tax reforms and their design impact reelection outcomes.

\section{A. Reform Types: PIT, CIT, and Indirect Tax Reforms}

In this section, we consider each type of tax reform separately as an explanatory variable (while controlling for the other). We first examine whether the political costs differ for direct and indirect tax reforms. The underlying idea is that tax reforms that have a broader economic scope-i.e., reforms that affect a larger share of the population and/or have a larger impact on the median voter or are targeted toward specific interest groups—could be costlier politically. ${ }^{18}$

The results in Table 4 (column II) show that that a 1 percentage point of GDP indirect tax consolidation entails large political costs, lowering the probability of reelection of the incumbent

\footnotetext{
18 It could also be the case that politicians that view voters as averse to increased taxation tend to pick forms of taxation that are less visible to the decisive voters whose votes they care about. Similarly, governments, who take preferences and ideology of the voters into account, may be willing to implement reforms that favor swing voters, i.e. the most "mobile" groups, which are ready to reward them with more votes when a policy proposal favors them.
} 
government party by about 12 percentage points. However, the effect of direct tax reform of a similar magnitude is considerably smaller (about 6 percentage points). These effects are economically but not statistically different from each other, which suggests that a closer look at direct tax reforms is warranted.

The results in Table 4 (column III) indicate that CIT reforms have a more significant political impact, lowering the probability of reelection of the current government by about 20 percentage points. The impact of PIT reforms is lower but not economically significant. The effects are statistically different from each other at the 10 percent level; the effects of PIT reforms are also statistically different from that of indirect tax reforms. The larger effect of CIT reforms can be explained by the fact that CIT increases directly affect corporate interest groups that potentially face lower costs to structure themselves into an organized pressure group and are politically "strong."

Similarly, the non-significant political consequence of PIT reforms could be driven by the fact that these reforms often include offsetting measures targeted toward specific groups. For instance, in addition to multiple brackets targeting particular constituencies being a prominent feature, PIT reforms can include changes to personal allowances, other married couples' specific allowances and deductions, tax credits (e.g., child tax credit), as well as special tax treatment of specific types of income (such reduced tax rates on capital income or capital gains), all of which tend to have a differential impact on taxpayers.

We also find preliminary evidence that tax increases and decreases have asymmetric effects on election outcomes (appendix Table A4). Indirect tax and PIT increases hold political costs, though tax decreases are benign electorally. In the case of indirect taxes, voters actually reward governments who deliver lower taxes.

\section{B. Reform Composition}

We also examine whether the political costs differ for front and backloaded consolidations. Given electoral myopia, we should expect that reforms that change tax liabilities at the beginning of the consolidation plan would entail larger political costs. To address this, we estimate Equation (3) with the dummy variable $D_{i t}^{l}\left(D_{i t}^{h}\right)$ taking the value of $1(0)$ when the reform is front (back) loaded. We define the announced multi-year reform as frontloaded if at least 50 percent of the revenue yield is expected within the first year. We consider all announced one-year reforms as frontloaded. The results are reported in Table 5 .

Our findings indicate that frontloaded reforms, independent of their type, are costlier for governments. This is especially the case for PIT reforms, where frontloading reforms lowers the probability of reelection by over 40 percentage points. Piketty and Saez (2012) note that PIT typically represent between a third and a half of national income in OECD countries. Three quarters of this tax collection are borne on labor income, which could potentially explain the large electoral costs associated with PIT reforms that are frontloaded, and hence are more visible to the voters. 
Table 4. Effects of Different Taxes on the Probability of Reelection of the Government (marginal effects)

\begin{tabular}{|c|c|c|c|}
\hline & (I) & (II) & (III) \\
\hline All Tax Reforms & $\begin{array}{c}-\mathbf{0 . 0 8 4} * * * \\
(0.029)\end{array}$ & & \\
\hline Direct Tax Reforms & \multicolumn{3}{|c|}{$\begin{array}{l}-\mathbf{0 . 0 7 2 * *} \\
(0.031)\end{array}$} \\
\hline CIT Reforms & & & $\begin{array}{l}-\mathbf{0 . 2 0 7 * *} \\
(0.098)\end{array}$ \\
\hline PIT Reforms & & & $\begin{array}{l}\mathbf{- 0 . 0 2 3} \\
(0.035)\end{array}$ \\
\hline Indirect Tax Reforms & & $\begin{array}{c}-\mathbf{0 . 1 2 5 * *} \\
(0.054)\end{array}$ & $\begin{array}{c}-\mathbf{0 . 1 2 5 * *} \\
(0.051)\end{array}$ \\
\hline Observations & 860 & 860 & 860 \\
\hline Controls & Yes & Yes & Yes \\
\hline Time FE & Yes & Yes & Yes \\
\hline Clustering & Yes & Yes & Yes \\
\hline (Pseudo) R-squared & 0.074 & 0.047 & 0.074 \\
\hline Test for the difference in coefficients in (II) & & $(0.66)$ & $\begin{array}{c}* \\
(2.54)\end{array}$ \\
\hline Test for the difference in coefficients in (III) & & & $\begin{array}{c}* \\
(2.44)\end{array}$ \\
\hline $\begin{array}{l}\text { Note: }{ }^{*} p<0.10,{ }^{* *} p<0.05,{ }^{* \star *} p<0.01 . \text { The coef } \\
\text { GDP of tax-based consolidation on the probab } \\
\text { baseline Table } 2 \text {. Wald test ch2-statistics are in }\end{array}$ & $\begin{array}{l}\text { interpreted a } \\
\text { Controls (not }\end{array}$ & $\begin{array}{l}\text { fact of a on } \\
\text { for brevity }\end{array}$ & $\begin{array}{l}\text { age point of } \\
\text { ame as in }\end{array}$ \\
\hline
\end{tabular}

Table 5. Effects of Tax Reforms on the Probability of Reelection of the Government depending on the Composition of Reform (marginal effects)

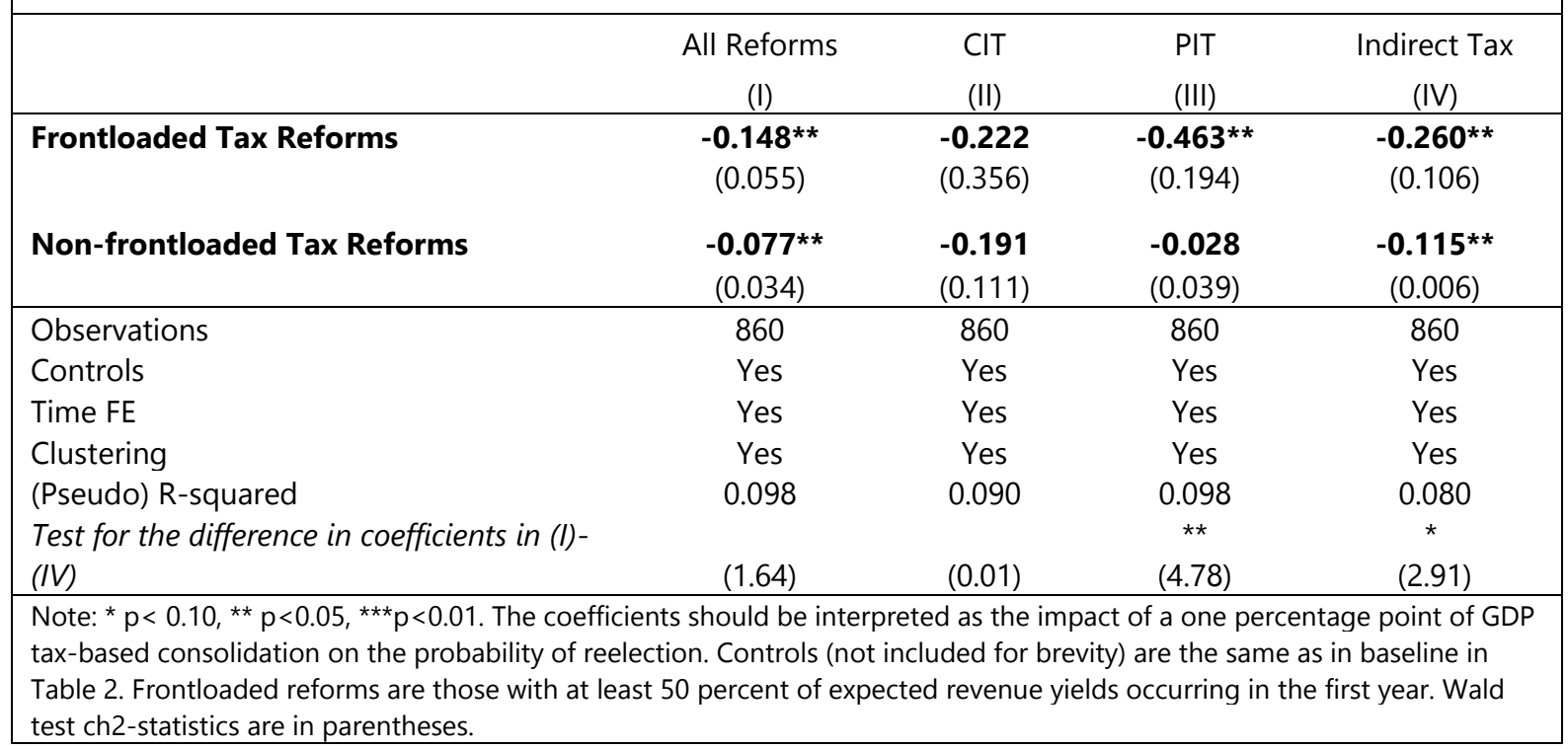




\section{Motivation Behind Reforms}

In this section, we examine the motivation of reforms using a three-step approach. First, we use the motivation of each reform identified by Dabla-Norris and Lima (2018), distinguishing between reforms aimed at supporting long-term growth and those undertaken to lower existing fiscal deficits and public debt (hereafter "consolidation measures") and other measures. ${ }^{19}$ Second, among these reforms, we focus on only tax increases. ${ }^{20}$ Third, we test whether consolidation tax measures entail larger electoral costs than tax measures announced for other purposes.

To the best of our knowledge, this is the first study looking at the impact of tax reforms on political outcomes depending on the motivation of reforms. We expect that measures presented as improving long-term growth prospects could be more welcome by voters than those aimed at consolidating existing deficits and debt. The results (reported in Table 6) indicate that consolidation tax reforms indeed lower the probability of reelection of the government by about 45 percentage points (column I). ${ }^{21}$ As expected, the electoral impact of contractionary tax reforms announced with the aim of increasing long-term growth is not economically significant (column II). ${ }^{22}$

Table 6. Effects of Consolidation Tax Reforms on the Probability of Reelection of the Government depending on the Motivation of the Reform (marginal effects)

\begin{tabular}{|c|c|c|}
\hline & $\begin{array}{c}\text { Consolidation } \\
\text { (I) } \\
\end{array}$ & $\begin{array}{l}\text { Long-term Growth } \\
\text { (II) }\end{array}$ \\
\hline \multirow[t]{2}{*}{ Tax Reform Motivation } & $-0.483^{* * *}$ & -0.094 \\
\hline & $(0.117)$ & $(0.084)$ \\
\hline Observations & & 860 \\
\hline Controls & & Yes \\
\hline Time FE & & Yes \\
\hline Clustering & & Yes \\
\hline \multirow[t]{2}{*}{ (Pseudo) R-squared } & & 0.090 \\
\hline & & $* * *$ \\
\hline Test for the difference in coefficients between (I) and (II) & & (7.8) \\
\hline $\begin{array}{l}\text { Note: }{ }^{*} \mathrm{p}<0.10,{ }^{* *} \mathrm{p}<0.05,{ }^{* * *} \mathrm{p}<0.01 \text {. The coefficients should } \\
\text { of GDP tax consolidation on the probability of reelection. Con } \\
\text { baseline Table } 2 \text {. Wald test ch2-statistics are in parentheses. }\end{array}$ & $\begin{array}{l}\text { eted as the imp } \\
\text { included for bre }\end{array}$ & $\begin{array}{l}\text { one percentage point } \\
\text { e the same as in }\end{array}$ \\
\hline
\end{tabular}

\footnotetext{
${ }^{19}$ The long-term growth reforms include measures similar to that announced by the Australian government in September 1985 or UK government in 1991 when some tax rates were increased to financed long-term growth considerations (see Dabla-Norris and Lima, 2018). Administrative reforms are mainly those aiming at improving the efficiency of tax system.

${ }^{20}$ We minimize omitted variable bias by controlling for tax decreases and-as previously-other factors that can affect reelection outcomes and tax reform implementation.

${ }^{21}$ Our results (available upon request) show that the impact of other measures on electoral outcomes is not statistically significant.

${ }^{22}$ We also test whether the implementation lags, mainly whether the impact of reforms on the political outcomes varies if the reforms is announced before and implemented after the reelections. The results-available upon request-are not statistically significant.
} 


\section{When Are Tax Refoms Most Costly?}

This section focuses on how the political and economic conditions prevailing at the time of reform introduction impact electoral outcomes. First, we analyze the role of political capital and political support for the incumbent government. Second, we test whether the political cost of tax reforms varies over the business cycles (e.g., during recessions or "normal" times).

\section{A. Timing of Reforms}

The literature provides relatively robust evidence that the timing of reforms in the electoral cycle affects election outcomes. This aspect of the reform design is closely related to the existence of electoral myopia, suggesting that voters pay more attention to government actions implemented in the run-up to elections (Ciminelli et al., 2019). The timing of reform is also linked to the political support for the government, which is often highest in the earlier period of an incumbent's term.

We test this hypothesis using Equation (3) with the dummy variable taking the value of 1 when the lag between the announcement and the election date is at least 8 quarters ( 2 years) before the election, and zero otherwise. The results reported in Table 7 confirm previous findings that tax reforms announced in the run-up to the election have larger and statistically significant adverse effects on electoral outcomes.

Interestingly, our earlier findings suggested that voters, on average, do not penalize governments for PIT reforms. This result is more nuanced when we consider the timing of reforms (column III). PIT reforms have no impact on reelection odds when announced 8 quarters (or 2 years) before the beginning of the government's new mandate but are heavily penalized by voters (the probability of reelection falls by almost 15 percentage points) when announced in the run-up to the next election. The impact of indirect tax reforms is also larger close to elections (column IV). In contrast, CIT consolidation reforms are costly independently of timing of their announcement (column II).

Table 7. Effects of Tax Reforms on the Probability of Reelection of the Government depending on Timing of Reforms (marginal effects)

\begin{tabular}{|c|c|c|c|c|}
\hline & $\begin{array}{c}\text { All Reforms } \\
\text { (I) }\end{array}$ & $\begin{array}{l}\text { CIT } \\
\text { (II) }\end{array}$ & $\begin{array}{l}\text { PIT } \\
\text { (III) }\end{array}$ & $\begin{array}{l}\text { Indirect Tax } \\
\text { (IV) }\end{array}$ \\
\hline Tax Reforms Closer to Reelection & $\begin{array}{c}-\mathbf{0 . 1 5 5 * *} \\
(0.064)\end{array}$ & $\begin{array}{c}-\mathbf{0 . 3 0 8 * *} \\
(0.136)\end{array}$ & $\begin{array}{l}-\mathbf{0 . 1 6 0 *} \\
(0.094)\end{array}$ & $\begin{array}{c}-\mathbf{0 . 3 2 8 * * *} \\
(0.104)\end{array}$ \\
\hline Tax Reforms Further from Reelection & $\begin{array}{l}-0.041 \\
(0.027) \\
\end{array}$ & $\begin{array}{r}-0.199 * \\
(0.114)\end{array}$ & $\begin{array}{l}-\mathbf{0 . 0 1 2} \\
(0.347) \\
\end{array}$ & $\begin{array}{l}-\mathbf{0 . 0 9 0} \\
(0.060) \\
\end{array}$ \\
\hline Observations & 860 & 860 & 860 & 860 \\
\hline Controls & Yes & Yes & Yes & Yes \\
\hline Time FE & Yes & Yes & Yes & Yes \\
\hline Clustering & Yes & Yes & Yes & Yes \\
\hline (Pseudo) R-squared & 0.182 & 0.077 & 0.078 & 0.071 \\
\hline $\begin{array}{l}\text { Test for the difference in coefficients in (I)- } \\
\text { (IV) }\end{array}$ & $\begin{array}{c}* \\
(2.64)\end{array}$ & $(0.39)$ & $(2.16)$ & $\begin{array}{c}* * \\
(41.15)\end{array}$ \\
\hline
\end{tabular}




\section{B. Role of Political Conditions}

\section{Political Capital}

In this section we examine the role of political capital in driving electoral outcomes. We proxy political capital by the share of votes that the incumbent government party has in Parliament after the first elections. Specifically, we consider that a government has currently more (less) political capital if the share of votes of the ruling party is above (below) the country-specific median over the sample period. Again. we use the country-specific median to account for country-specific political features (e.g., presence of multiparty systems). We modify Equation (3) using the dummy variable $D_{i t}^{l}\left(D_{i t}^{h}\right)$ taking the value of $1(0)$ when the government party has less (more) political capital. The results (reported in Table 8) confirm that the electoral costs are not material for governments with strong political capital. Consistent with our previous finding, we find that political support for PIT reforms is conditional: PIT reforms do not affect election outcomes when implemented if the government has strong policy support (column III).

Table 8. Effects of Tax Reforms on the Probability of Reelection of the Government depending on the Political Support for the Government (marginal effects)

\begin{tabular}{|c|c|c|c|c|}
\hline & $\begin{array}{l}\text { All Reforms } \\
(\mathrm{I})\end{array}$ & $\begin{array}{l}\text { CIT } \\
\text { (II) }\end{array}$ & $\begin{array}{l}\text { PIT } \\
(\text { III) }\end{array}$ & $\begin{array}{l}\text { Indirect Tax } \\
\text { (IV) }\end{array}$ \\
\hline \multirow{2}{*}{$\begin{array}{l}\text { Tax Reforms with Lower Political } \\
\text { Support }\end{array}$} & $-0.171 * * *$ & $-0.271^{* *}$ & $-0.268^{* *}$ & $-0.207^{* *}$ \\
\hline & $(0.038)$ & (0.107) & $(0.027)$ & $(0.056)$ \\
\hline \multirow[t]{2}{*}{$\begin{array}{l}\text { Tax Reforms with Higher Political } \\
\text { Support }\end{array}$} & -0.038 & -0.129 & -0.029 & -0.012 \\
\hline & $(0.054)$ & (0.199) & $(0.045)$ & $(0.136)$ \\
\hline Observations & 860 & 860 & 860 & 860 \\
\hline Controls & Yes & Yes & Yes & Yes \\
\hline Time FE & Yes & Yes & Yes & Yes \\
\hline Clustering & Yes & Yes & Yes & Yes \\
\hline (Pseudo) R-squared & 0.083 & 0.078 & 0.078 & 0.080 \\
\hline Test for the difference in coefficients in (I)- & ** & & * & $* *$ \\
\hline (IV) & $(3.81)$ & $(0.48)$ & $(6.41)$ & $(4.81)$ \\
\hline
\end{tabular}

\section{Political Orientation and Preferences}

The literature provides mixed evidence on how the political orientation of the government affects the probability of reelection following reforms. On the one hand, supporters of the ruling party may not penalize the government for reforms that harm their political preference and interests if they consider the reforms as economically necessary. On the other hand, political supporters could penalize the government even more for undertaking actions that go against their policy 
preferences and interests. ${ }^{23}$ Voter choices may also depend on the redistributive gains associated with particular tax reform proposals weighed against the deadweight costs associated with tax increases. $^{24}$

We test for this by estimating Equation (3) with the dummy variable $D_{i t}^{l}\left(D_{i t}^{h}\right)$ that takes the value of $1(0)$ when the government party is a left (right) wing party. The results (Table 9) show that tax consolidations are generally costlier for right-wing governments (column I), that typically tend to be pro-business.

Table 9. Effects of Tax Reforms on the Probability of Reelection of the Government depending on Political Orientation (marginal effects)

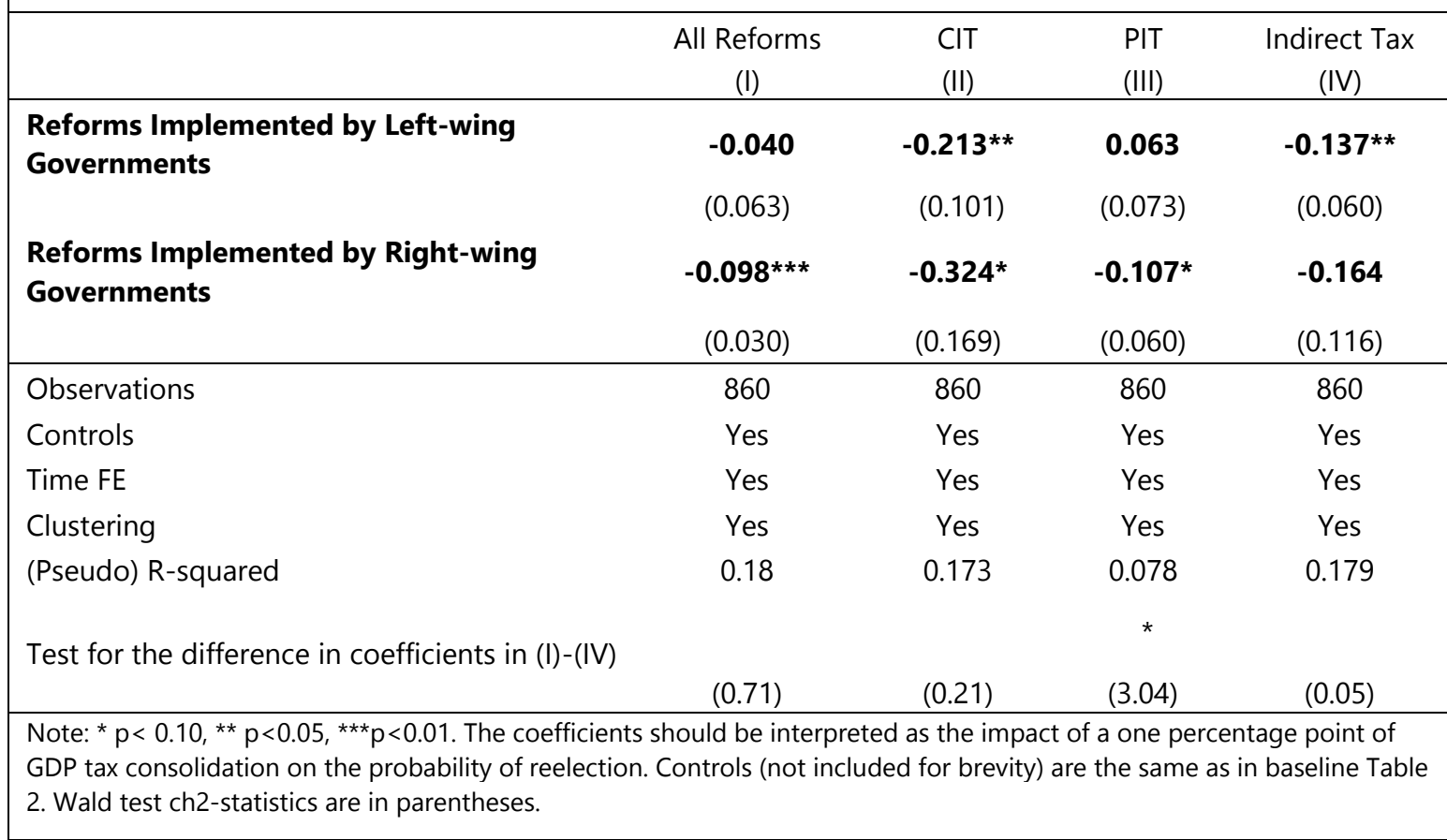

CIT reforms (column II) lower the probability of reelection of the incumbent government by about 32 percentage points when the government is a right-wing party and by 20 percent, on average, for a left-wing government. Indirect tax increases announced by left-wing governments, however, are costly electorally. Interestingly, we find that PIT reforms (column III) lower the probability of reelection by 10 percentage points for right-wing governments, but the effect is statistically insignificant for left-wing governments.

\footnotetext{
${ }^{23}$ Cukierman and Tommasi (1998), however, note that it might is easier for leaders that are ideologically distant from certain types of reforms to elicit the necessary support to implement them.

24 If voters decide between competing tax proposals by balancing the redistributive gains (if their income is below the mean) against deadweight costs (which harm everyone) and if marginal deadweight costs are increasing in tax rates whereas marginal redistributive gains or losses are not, then differences in deadweight costs could assume greater importance the higher is the average of the marginal tax rates offered by the parties, to the detriment of those proposing higher taxes (see Alt, Preston, and Sibeita 2010).
} 


\section{Role of Economic Factors}

In this section, we test whether the political costs of tax reforms depend on economic conditions prevailing at the time of the reform announcement.

\section{Economic Conditions}

The asymmetric impact of fiscal policy across the business cycle has been widely discussed in the literature (see, among others, Auerbach, and Gorodnichenko, 2012; Born, Müller, and Pfiefer, 2019). While some findings point to a larger impact of fiscal shocks during downturns, others suggest that the fiscal multiplier does not vary between expansions and recessions (Ramey, 2011). Moreover, the short-term impact of tax reform on growth could be an important channel affecting political outcomes (Dabla-Norris and Lima, 2018). If the economic impact of tax reforms is state dependent, reforms implemented during recessions could be particularly costly for governments.

We test this notion by analyzing the impact of tax reforms on the probability of reelection depending on whether reforms are introduced during recessions or in "normal" times. ee identify recession episodes when GDP growth in a country is below $25^{\text {th }}$ percentile of the country-specific distribution. ${ }^{25}$ Specifically, we estimate Equation (3) with the dummy variable $D_{i t}^{l}\left(D_{i t}^{h}\right)$ that takes the value of $1(0)$ when a country GDP growth is below (above) $25^{\text {th }}$ percentile.

The results (Table 10) indicate that the probability of reelection of the incumbent party is significantly lower when reforms are announced during recessions. In the case of PIT reforms, the likelihood of reelection is reduced by about 36 percentage points. These results are consistent with previous findings that reforms are particularly costly in recessions, and they highlight the importance of accounting for economic conditions when designing reform packages.

\section{Tax Progressivity}

Progressive income taxation (i.e. designing a tax system so that the average tax rate rises with income) allows for greater redistribution. However, voters' preferences for redistribution can vary with income. Low observed levels of tax progressivity in some countries could reflect the fact that low- and middle classes have less political weight in determining tax policy outcomes. Instead, it may be that better-off individuals have more political influence, for example, through lobbying, access to the media, and greater political engagement. ${ }^{26}$ This would imply that voters penalize governments more for reforms that increase PIT rates or reduce deductions in these countries.

To test this, we analyze the impact of tax reforms on the probability of reelection depending on whether reforms are introduced in countries with low income tax progressivity compared to countries with high PIT progressivity. We compute the indicator of PIT progressivity as: 1- (100-marginal tax rate)/(100-average tax rate) and identify high PIT progressivity countries where this is above 25 th percentile of the country sample. Specifically, we estimate Equation (3) with the dummy variable

\footnotetext{
${ }^{25}$ As robustness, we also considered alternative definitions of recessions.

${ }^{26}$ In models of probabilistic voting, for instance, the weight given to different voters' interest could be interpreted as reflecting the relative political influence of the voters.
} 
$D_{i t}^{h}\left(D_{i t}^{l}\right)$ that takes the value of $1(0)$ when the PIT progressivity indicator is above (below) the 25th percentile.

Table 10. Effects of Tax Reforms on the Probability of Reelection of the Government depending on Growth Regimes (marginal effects)

\begin{tabular}{|c|c|c|c|c|}
\hline & $\begin{array}{c}\text { All Reforms } \\
\text { (I) }\end{array}$ & $\begin{array}{l}\text { CIT } \\
\text { (II) }\end{array}$ & $\begin{array}{l}\text { PIT } \\
\text { (III) }\end{array}$ & $\begin{array}{c}\text { Indirect Tax } \\
\text { (IV) }\end{array}$ \\
\hline \multirow[t]{2}{*}{ Tax Reforms implemented during Recessions } & $-0.215^{* *}$ & -0.213 & $-0.365^{* *}$ & -0.378 \\
\hline & $(0.109)$ & $(0.264)$ & $(0.061)$ & $(0.267)$ \\
\hline \multirow[t]{2}{*}{ Tax Reforms implemented during “Normal Times” } & $-0.041^{*}$ & -0.073 & -0.043 & -0.058 \\
\hline & $(0.0198)$ & $(0.049)$ & $(0.034)$ & $(0.035)$ \\
\hline Observations & 860 & 860 & 860 & 860 \\
\hline Controls & Yes & Yes & Yes & Yes \\
\hline Time FE & Yes & Yes & Yes & Yes \\
\hline Clustering & Yes & Yes & Yes & Yes \\
\hline (Pseudo) R-squared & 0.1430 & 0.1420 & 0.1430 & 0.143 \\
\hline \multirow[t]{2}{*}{ Test about the difference in coefficients in (I)-(IV) } & * & & $* * *$ & \\
\hline & $(2.45)$ & $(0.27)$ & $(21.10)$ & $(1.40)$ \\
\hline \multicolumn{5}{|c|}{$\begin{array}{l}\text { Note: }{ }^{*} p<0.10,{ }^{* *} p<0.05,{ }^{* *} p<0.01 \text {. The coefficients should be interpreted as the impact of a one percentage point } \\
\text { of GDP tax consolidation on the probability of reelection. Controls (not included for brevity) are the same as in } \\
\text { baseline Table } 2 \text {. Wald test ch2-statistics are in parentheses. }\end{array}$} \\
\hline
\end{tabular}

The results reported in Table 11 suggest that the electoral penalty for tax reforms tends to be higher in countries with low levels of tax progressivity. These electoral costs are particularly pronounced in the case of PIT reforms in these countries, reducing the likelihood of reelection by around 40 percentage points.

Table 11. Effects of Tax Reforms on the Probability of Reelection of the Government depending on PIT Progressivity (marginal effects)

\begin{tabular}{|c|c|c|}
\hline & $\begin{array}{l}\text { All Reforms } \\
\text { (I) }\end{array}$ & $\begin{array}{l}\text { PIT } \\
\text { (II) }\end{array}$ \\
\hline \multirow[t]{2}{*}{ Tax Reforms in Countries with Higher Tax Progressivity } & $-0.034^{*}$ & -0.040 \\
\hline & $(0.021)$ & $(0.037)$ \\
\hline \multirow[t]{2}{*}{ Tax Reforms in Countries with Lower Tax Progressivity } & $-0.355^{* * *}$ & $-0.395^{* * *}$ \\
\hline & $(0.126)$ & $(0.087)$ \\
\hline Observations & 860 & 860 \\
\hline Controls & Yes & Yes \\
\hline Time FE & Yes & Yes \\
\hline Clustering & Yes & Yes \\
\hline (Pseudo) R-squared & 0.4348 & 0.4276 \\
\hline \multirow{2}{*}{ Test about the difference in coefficients in (I)- (II) } & ** & *** \\
\hline & $(6.10)$ & $(13.93)$ \\
\hline
\end{tabular}




\section{Conclusions}

Tax-based consolidations affect public support for the governments implementing them. Political costs, however, depend strongly on the design of the reform package and prevailing political and economic conditions. We find that indirect tax policy reforms generally entail larger electoral costs than direct tax consolidation measures. Within direct taxes, electoral costs are higher for CIT reforms rather than changes in PIT. Frontloaded consolidations, especially if they pertain to PIT reforms, are more costly than gradual reforms. Consolidation tax measures primarily aimed at lowering existing deficits and debt entail larger electoral costs than consolidation measures aimed at improving long-term growth prospects. We also find that electoral costs are, on average, lower for left-wing governments, when tax consolidation measures are implemented by governments with stronger political capital, and if announced earlier in the election cycle. In contrast, reforms undertaken in the earlier period of an incumbent's term do not affect election prospects. We also find that voters tend to penalize governments for undertaking tax consolidation measures during recessions, particularly in the case of PIT reforms, and in countries with low tax progressivity.

We have focused on the short-term macroeconomic and political factors that could affect electoral outcomes, but structural factors such as labor market and product rigidities and their interaction with tax reforms could also be pertinent. Another potential avenue of research is the differential impact of tax base and rate measures, as these measures potentially target different segments of voters. Finally, we find that PIT reforms are associated with significant electoral costs only if they are frontloaded, if the government has a weak mandate, if announced during recessions and in countries where the tax system is less progressive. This suggests that examining the interaction between PIT reforms, redistribution and inequality could be important. We leave these and other questions for future research. 


\section{References}

Alesina, A., and N. Roubini (1992) "Political Cycles in OECD Economies." Review of Economic Studies 59(4): 663-688.

Alesina, A., R. Perotti, and J. Tavares (1998) "The Political Economy of Fiscal Adjustments." Brookings Papers on Economic Activity, 1: 197-248.

Alesina, A., C. Favero, and F. Giavazzi (2015). "The Output Effect of Fiscal Consolidation Plans," Journal of International Economics, 96/S1, 19-42.

Alesina, A. F., C. Favero, and F. Giavazzi (2019). Austerity. When It Works and When It Doesn't? Princeton University Press.

Alesina, A. F., G. Ciminelli, D. Furceri and G. Saponaro (2019). 'Austerity and Elections: New Empirical Evidence" IMF Working Paper (Forthcoming).

Alt, J., Preston, I. and Sibieta, L. (2010), "The Political Economy of Tax Policy." In Adam, S., Besley, T., Blundell, R., Bond, S., Chote, R., Gammie, M., Johnson, P., Myles, G. and Poterba, J. (eds) Dimensions of Tax Design, Oxford: Oxford University Press.

Auerbach, A., and Y. Gorodnichenko (2012). "Measuring the Outpus Responses to Fiscal Policy." American Economic Juournal: Economic Policy 4 (2): 1-27.

Born, B., G. Müller, and J. Pfeifer (2019) "Does Austerity Pay Off?" Review of Economics and Statistics (forthcoming).

Brender, A., and A. Drazen (2008) "How Do Budget Deficits and Economic Growth Affect Reelection Prospects? Evidence from a Large Panel of Countries." American Economic Review 98 (5): 2203-2220.

Ciminelli, G., D. Furceri, J. Ge, J.D. Ostry, and C, Papageorgiou (2019). The Political Costs of Reforms: Fear or Reality? IMF Staff Dicussion Note (Forthcoming).

Cukierman, A., and M. Tommasi (1988) "When Does It Take a Nixon to Go to China?" American Economic Review, 88(1), pp. 180-97.

Dabla-Norris, E. and F. Lima (2018). "The Macroeconomic Effect of Tax Changes." IMF Working Paper 18/220.

Devries, P., J. Guajardo, D. Leigh, and A. Pescatori, "A New Action-based

Dataset of Fiscal Consolidation," IMF Working Papers, 2011, (WP/11/128), 1-91.

Dixit, A. and J. Londregan (1998). "Fiscal Federalism and Redistributive Politics". Journal of Public Economics, 68(2), pp. 153-180. 
Drazen, A. (2001). "The Political Business Cycle after 25 Years." In B. Bernanke and K. Rogoff (Eds.), NBER Macroeconomics Annual 2000, Volume 15 (pp. 75-138). MIT Press.

Ehrhart, H. (2013) "Elections and the Structure of Taxation in Developing Countries." Banque de France Working Paper No. 419.

Ilzetski, E., (2018) "Tax Reform and the Political Economy of the Tax Base." Journal of Public Economics 164, 297-210.

Laeven, L. and F. Valencia (2018). "Systematic Banking Crises Revisited." IMF Working Paper $18 / 206$.

Lindbeck, A. and W.W. Weibull (1983). "Balanced-budget Redistribution as the Outcome of Political Competition." Public Choice, 52, pp. 273-297.

Meltzer, A. and S. Richard (1981). 'A Rational Theory of the Size of the Government.' Journal of Political Economy 89 (5): 914-927.

Mertens, K. and M. Ravn (2012). "Empirical Evidence on the Aggregate Effects of Anticipated and Unanticipated US Tax Policy Shocks." American Economic Journal: Economic Policy 4 (2): 145-181.

Mertens, K. and M. Ravn (2013). "The Dynamic Effects of Personal and Corporate Income Tax Changes in the United States," American Economic Review, 103 (4), 1212-1247.

Persson, T. and G. Tabellini (2002) Political Economics: Explaining Economic Policy Cambridge, MA: The MIT Press.

Piketty, T. and E. Saez (2012) "Optimal Labor Income Taxation". NBER WP18521.

Ramey, V. (2011). "Can Government Purchases Stimulate the Economy?" Journal of Economic Literature 49 (3): 673-685. 
Annex A1. Data Sources

\begin{tabular}{|c|c|c|c|}
\hline Data & Measures & Frequency & Sources \\
\hline Election outcomes & $\begin{array}{l}\text { Dates, Number of Votes, Political Party } \\
\text { Information, Other Information about } \\
\text { the elections Outcomes }\end{array}$ & & $\begin{array}{l}\text { Global Elections } \\
\text { Database, Database of } \\
\text { Political Institutions, and } \\
\text { National Election } \\
\text { Database }\end{array}$ \\
\hline Tax Reforms & $\begin{array}{l}\text { Tax reforms identified using the } \\
\text { narrative database for } 10 \text { OECD } \\
\text { countries, Quarterly data, }\end{array}$ & $\begin{array}{l}\text { Quarterly } \\
\text { 1980Q1- } \\
\text { 2014Q4 }\end{array}$ & $\begin{array}{l}\text { Dabla-Norris and Lima } \\
\text { (2018) }\end{array}$ \\
\hline $\begin{array}{l}\text { Fiscal consolidation } \\
\text { measures }\end{array}$ & $\begin{array}{l}\text { Spending and tax-based measures } \\
\text { using the narrative database for } 16 \\
\text { OECD countries, }\end{array}$ & $\begin{array}{l}\text { Annual } \\
1980-2014\end{array}$ & $\begin{array}{l}\text { Alesina, A., C. Favero, and } \\
\text { F. Giavazzi (2015) }\end{array}$ \\
\hline $\begin{array}{l}\text { General } \\
\text { government debt }\end{array}$ & & $\begin{array}{l}\text { Annual } \\
1980-2014\end{array}$ & IMF Fiscal Rule Dataset \\
\hline $\begin{array}{l}\text { Quarterly Tax Ratio } \\
\text { and GDP }\end{array}$ & & $\begin{array}{l}\text { Quarterly } \\
\text { 1980Q1- } \\
\text { 2013Q4 }\end{array}$ & $\begin{array}{l}\text { OECD Tax Database and } \\
\text { Dabla-Norris and Lima } \\
\text { (2018) }\end{array}$ \\
\hline $\begin{array}{l}\text { Other } \\
\text { Characteristics of } \\
\text { Tax System }\end{array}$ & $\begin{array}{l}\text { PIT progressivity, Various Tax-to-GDP } \\
\text { Ratios; Annual data }\end{array}$ & $\begin{array}{l}\text { Annual } \\
1980-2014\end{array}$ & OECD Tax Database \\
\hline $\begin{array}{l}\text { Other fiscal and } \\
\text { macroeconomic } \\
\text { variables }\end{array}$ & $\begin{array}{l}\text { Structural fiscal balance, nominal GDP, } \\
\text { real GDP per capita. Annual and } \\
\text { quarterly }\end{array}$ & $\begin{array}{l}\text { Annual } \\
\text { 1980-2014 } \\
\text { Quarterly } \\
\text { for GDP } \\
\text { 1980Q1- } \\
\text { 2013Q4 }\end{array}$ & $\begin{array}{l}\text { IMF World Economic } \\
\text { Outlook, OECD }\end{array}$ \\
\hline Financial Crisis & Systematic banking crises & $\begin{array}{l}\text { Annual } \\
1980-2017\end{array}$ & $\begin{array}{l}\text { Laeven and Valencia } \\
\text { (2018) }\end{array}$ \\
\hline
\end{tabular}


Annex A2. Selected Summary Statistics

\begin{tabular}{|c|c|c|c|}
\hline \multicolumn{4}{|c|}{ Table A2: Summary Statistics } \\
\hline & Mean & $\begin{array}{l}\text { Standard } \\
\text { Deviation }\end{array}$ & $\begin{array}{l}\text { Number of } \\
\text { Observations }\end{array}$ \\
\hline Elections (actual number) & & & 89 \\
\hline Government Party Reelected (actual number) & & & 49 \\
\hline Leader Reelected (actual number) & & & 39 \\
\hline $\begin{array}{l}\text { Government Party Reelected with at least the same number of } \\
\text { votes as in the previous elections (actual number) }\end{array}$ & & & 27 \\
\hline $\begin{array}{l}\text { \# of Left-Wing Government Ruling Parties per Country (actual } \\
\text { number) }\end{array}$ & & & 41 \\
\hline $\begin{array}{l}\text { \# of Right-Wing Government Ruling Parties per Country (actual } \\
\text { number) }\end{array}$ & & & 48 \\
\hline \multicolumn{4}{|l|}{ Other variables } \\
\hline $\begin{array}{l}\text { Public Support (Number of Votes of Government Ruling Party at } \\
\text { the Parliament at the Time of the Reform, in quarters) }\end{array}$ & 40.94 & 5.89 & \\
\hline $\begin{array}{l}\text { Lag between Reform Announcement Tax Reforms and Reelection } \\
\text { (in quarters) }\end{array}$ & 8.27 & 5.95 & \\
\hline \multicolumn{4}{|l|}{ All Reforms } \\
\hline CIT reforms (in percent of GDP) & 0.09 & 0.77 & \\
\hline PIT reforms (in percent of GDP) & 0.06 & 1.33 & \\
\hline Indirect tax reforms (in percent of GDP) & 0.54 & 0.99 & \\
\hline Total tax reforms (in percent of GDP) & 0.69 & 1.70 & \\
\hline \multicolumn{4}{|l|}{ Only Tax Increases } \\
\hline CIT reforms (in percent of GDP) & 0.40 & 0.79 & \\
\hline PIT reforms (in percent of GDP) & 0.72 & 0.91 & \\
\hline Indirect tax reforms (in percent of GDP) & 0.90 & 0.95 & \\
\hline Total tax reforms (in percent of GDP) & 1.32 & 1.47 & \\
\hline PIT Progressivity (percent) & 25.8 & 9.3 & \\
\hline Real GDP Growth (percent) & 2.1 & 1.9 & \\
\hline Real GDP Growth (change over 2 years) & 1.32 & 1.39 & \\
\hline Public debt-to-GDP (percent) & 53.5 & 30.5 & \\
\hline Structural balance-to-GDP (change over 2 years) & -0.21 & 2.52 & \\
\hline
\end{tabular}


Annex A3. Effects of Tax Reforms on the Probability of Reelection of the Government: Alternative Database

Table A3: Effects of Tax Reforms on the Probability of Reelection of the Government (marginal effects): Alesina, Favero and Giavazzi (2015) Database

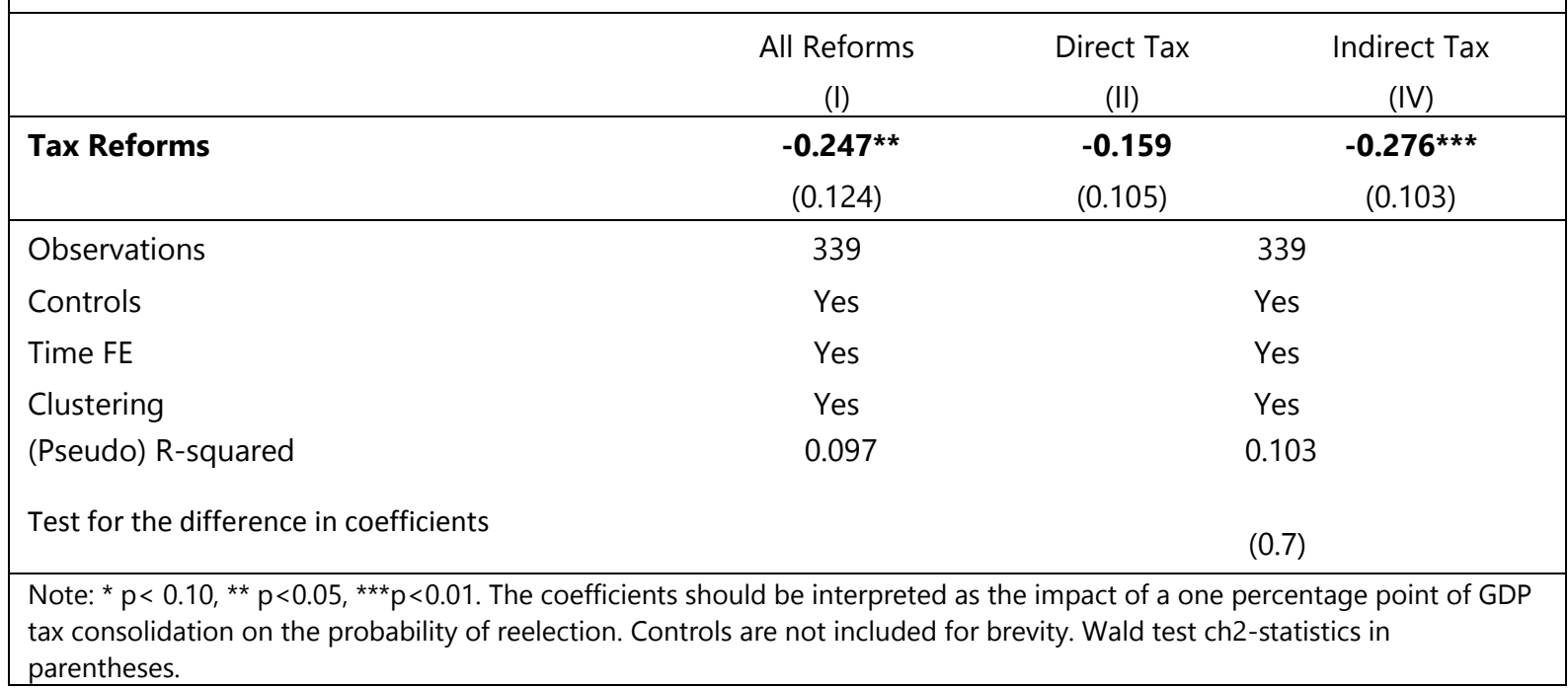

Annex A4. Differential Impact of Positive versus Negative Tax Reforms

Table A4: Effects of Tax Reforms on the Probability of Reelection of the Government depending on the Direction of Tax Reforms (marginal effects)

\begin{tabular}{|c|c|c|c|c|}
\hline & $\begin{array}{l}\text { All Reforms } \\
\text { (I) }\end{array}$ & $\begin{array}{l}\text { CIT } \\
\text { (II) }\end{array}$ & $\begin{array}{l}\text { PIT } \\
\text { (III) }\end{array}$ & $\begin{array}{l}\text { Indirect Tax } \\
\text { (IV) }\end{array}$ \\
\hline \multirow[t]{2}{*}{ Tax increases } & $-0.165^{* * *}$ & $-0.125^{*}$ & $-0.228^{* * *}$ & $-0.229 * * *$ \\
\hline & $(0.058)$ & $(0.070)$ & $(0.071)$ & $(0.073)$ \\
\hline \multirow[t]{2}{*}{ Tax decreases } & -0.052 & -0.111 & 0.007 & $-0.166^{*}$ \\
\hline & $(0.073)$ & $(0.082)$ & $(0.086)$ & $(0.095)$ \\
\hline Observations & 860 & 860 & 860 & 860 \\
\hline Controls & Yes & Yes & Yes & Yes \\
\hline Time FE & Yes & Yes & Yes & Yes \\
\hline Clustering & Yes & Yes & Yes & Yes \\
\hline (Pseudo) R-squared & 0.074 & 0.069 & 0.075 & 0.079 \\
\hline Test for the difference in coefficients & $(1.70)$ & $(0.02)$ & $\begin{array}{c}* * \\
(5.84)\end{array}$ & $(0.31)$ \\
\hline \multicolumn{5}{|c|}{$\begin{array}{l}\text { Note: }{ }^{*} p<0.10,{ }^{* *} p<0.05,{ }^{* * *} p<0.01 \text {. The results are based on Equation (3) with the reform indicator taking } \\
\text { values of } 1 \text { for the tax increases and zero otherwise. The coefficients should be interpreted as the impact of an } \\
\text { announcement of tax increases or decreases on the probability of reelection. Controls (not included for brevity) } \\
\text { are the same as in baseline Table } 2 . \text { Wald test ch2-statistics are in parentheses. }\end{array}$} \\
\hline
\end{tabular}


Annex A5. Effects of Tax Reforms on the Probability of Reelection of the Government: Alternative Measures of Economic Perfromance

Table A5. Effects of Tax Reforms on the Probability of Reelection of the Government: Alternative Measures of Economic Performance (marginal effects)

\begin{tabular}{|c|c|c|c|}
\hline & $\begin{array}{c}\text { Ruling Party } \\
\text { (I) }\end{array}$ & $\begin{array}{c}\text { Ruling Party } \\
\text { (II) }\end{array}$ & $\begin{array}{c}\text { Ruling Party } \\
\text { (III) }\end{array}$ \\
\hline Tax Reforms & $\begin{array}{c}-\mathbf{0 . 0 8 4} 4^{* * *} \\
(0.029)\end{array}$ & $\begin{array}{c}-\mathbf{0 . 0 8 6 * * *} \\
(0.029)\end{array}$ & $\begin{array}{c}\mathbf{- 0 . 0 9 0 * * *} \\
(0.029)\end{array}$ \\
\hline Structural fiscal balance (change 2 years) & $\begin{array}{c}-0.041^{* * *} \\
(0.006)\end{array}$ & $\begin{array}{c}-0.039 * * * \\
(0.006)\end{array}$ & $\begin{array}{c}-0.035^{\star * *} \\
(0.006)\end{array}$ \\
\hline Initial public debt level (percent of GDP) & $\begin{array}{l}-0.141^{* *} \\
(0.062)\end{array}$ & $\begin{array}{l}-0.178^{* *} \\
(0.062)\end{array}$ & $\begin{array}{c}-0.189 * * \\
(0.061)\end{array}$ \\
\hline Financial crises & $\begin{array}{l}-0.079 * \\
(0.492)\end{array}$ & $\begin{array}{c}-0.105^{\star *} \\
(0.053)\end{array}$ & $\begin{array}{c}-0.126^{* *} \\
(0.053)\end{array}$ \\
\hline Real GDP per capita (log, change over 2 year) & $\begin{array}{c}0.059 * * * \\
(0.012)\end{array}$ & & $\begin{array}{c}0.059 * * * \\
(0.012)\end{array}$ \\
\hline Real GDP growth in the election year & & $\begin{array}{l}0.034^{* * *} \\
(0.009)\end{array}$ & \\
\hline Real GDP growth 6 month ahead of the elections & & & $\begin{array}{c}0.041^{* * *} \\
(0.013)\end{array}$ \\
\hline Political Orientation of the Government (1-right; 0 -left) & $\begin{array}{l}0.041^{*} \\
(0.284)\end{array}$ & $\begin{array}{l}0.050 * \\
(0.290) \\
\end{array}$ & $\begin{array}{l}0.064^{\star} \\
(0.028) \\
\end{array}$ \\
\hline Observations & 860 & 860 & 854 \\
\hline Time FE & Yes & Yes & Yes \\
\hline Clustering by time & Yes & Yes & Yes \\
\hline (Pseudo) R-squared & 0.071 & 0.071 & 0.067 \\
\hline
\end{tabular}


Annex A6. Effects of Tax Reforms on the Probability of Reelection of the Government: Alternative Standard Errors Clustering

\begin{tabular}{|c|c|c|c|}
\hline \multicolumn{4}{|c|}{$\begin{array}{l}\text { Table A6. Effects of Tax Reforms on the Probability of Reelection of the } \\
\text { Standard Errors Clustering (marginal effects) }\end{array}$} \\
\hline & $\begin{array}{l}\text { Ruling Party } \\
\text { (I) }\end{array}$ & $\begin{array}{l}\text { Ruling Party } \\
\text { (II) }\end{array}$ & $\begin{array}{l}\text { Ruling Party } \\
\text { (III) }\end{array}$ \\
\hline \multirow[t]{2}{*}{ Tax Reforms } & $-0.084^{* * *}$ & $-0.084^{* * *}$ & $-0.084^{* * *}$ \\
\hline & $(0.029)$ & $(0.028)$ & $(0.027)$ \\
\hline \multirow[t]{2}{*}{ Structural fiscal balance (change 2 years) } & $-0.041^{* * *}$ & $-0.041^{* * *}$ & $-0.041^{* * *}$ \\
\hline & $(0.006)$ & $(0.006)$ & $(0.007)$ \\
\hline \multirow[t]{2}{*}{ Initial public debt level (percent of GDP) } & $-0.141^{\star *}$ & $-0.014^{\star *}$ & $-0.014^{\star \star}$ \\
\hline & $(0.062)$ & $(0.062)$ & $(0.062)$ \\
\hline \multirow[t]{2}{*}{ Financial crises } & $-0.079 *$ & -0.079 & -0.079 \\
\hline & $(0.492)$ & $(0.050)$ & $(0.062)$ \\
\hline \multirow[t]{2}{*}{ Real GDP per capita (log, change over 2 year) } & $0.059 * * *$ & $0.059 * * *$ & $0.059 * * *$ \\
\hline & $(0.012)$ & $(0.012)$ & $(0.014)$ \\
\hline \multirow[t]{2}{*}{ Political Orientation of the Government (1-right; 0-left) } & 0.041 & 0.420 & 0.422 \\
\hline & $(0.284)$ & $(0.029)$ & $(0.054)$ \\
\hline Observations & 860 & 860 & 860 \\
\hline Time FE & Yes & Yes & Yes \\
\hline Clustering by time & Yes & & \\
\hline Clustering by time and elections & & Yes & \\
\hline Clustering by time and country & & & Yes \\
\hline (Pseudo) R-squared & 0.074 & 0.074 & 0.074 \\
\hline
\end{tabular}

